\title{
Genetic analysis for designing an ideotype of high-yielding sorghum based on existing lines performance
}

\author{
DESTA WIRNAS ${ }^{1, \bullet}$, NENI OKTANTI ${ }^{2}$, HANA NUR RAHMI ${ }^{2}$, DEWI ANDRIANI ${ }^{3}$, FATURRAHMAN ${ }^{3}$, \\ ERIN PUSPITA RINI ${ }^{1}$, SITI MARWIYAH ${ }^{1}$, TRIKOESOEMANINGTYAS ${ }^{1}$, DIDY SOPANDIE $^{1}$ \\ ${ }^{1}$ Department of Agronomy and Horticulture, Faculty of Agriculture, Institut Pertanian Bogor. Jl. Meranti, Kampus IPB Darmaga, Bogor 16680, West \\ Java, Indonesia. Tel./fax.: +62-251-86293535, `email: desta@apps.ipb.ac.id \\ ${ }^{2}$ Program of Agronomy and Horticulture, Department of Agronomy and Horticulture, Faculty of Agriculture, Institut Pertanian Bogor. J1. Meranti, \\ Kampus IPB Darmaga, Bogor 16680, West Java, Indonesia \\ ${ }^{3}$ Program of Plant Breeding and Biotechnology, Department of Agronomy and Horticulture, Faculty of Agriculture, Institut Pertanian Bogor. Jl. Meranti, \\ Kampus IPB Darmaga, Bogor 16680, West Java, Indonesia
}

Manuscript received: 17 September 2021. Revision accepted: 10 November 2021.

\begin{abstract}
Wirnas D, Oktanti N, Rahmi HN, Andriani D, Faturrahman, Rini EP, Marwiyah S, Trikoesoemaningtyas, Sopandie D. 2021. Genetic analysis for designing an ideotype of high-yielding sorghum based on existing lines performance. Biodiversitas 22: 5286-5292. Sorghum is a potential crop as an alternative and substitutes food source for rice or wheat. The ideal type of sorghum design for a highyielding trait is needed to streamline the process of selecting the best genotype that can be developed into pure lines and released as varieties. The research purpose was to design the ideal type of sorghum based on the morphological, physiological, and agronomic characters that contribute to a high-yielding trait. The research was carried out at the Agriculture Research Center for Biotechnology and Genetic Resources, Bogor, West Java, Indonesia and experimental field of IPB University, Bogor, Indonesia. The genetic materials used in this study consisted of $56 \mathrm{~F}_{5}$ sorghum lines advanced from three segregating populations and 8 check varieties. The ideal type of sorghum to obtain a genotype with high grain weight per panicle was to have a phenotypic value of $150-235 \mathrm{~cm}$ for plant height (medium plant height). The physiological and agronomic characters obtained to design the ideal type of sorghum were stem diameter, leaf number, flag leaf area, leaf greenness, green leaf percentage, and panicle diameter with the minimum value for the traits are $17 \mathrm{~mm}$, $10,209 \mathrm{~cm}^{2}, 44 \mathrm{CCI}$ units, $48 \%$, and $49 \mathrm{~mm}$, respectively. This ideotype is going to be used as selection criteria for selection of highyielding sorghum genotypes.
\end{abstract}

Keywords: Grain, ideal crop, selection, sorghum

\section{INTRODUCTION}

Sorghum (Sorghum bicolor $(\mathrm{L}$.$) Moench, 2 \mathrm{n}=20$ ) is one of the main cereal crops in the world grown in tropical and semi-tropical regions (Reddy et al. 2005). Sorghum is a source of food and feed in several provinces in Indonesia, such as West Nusa Tenggara and East Nusa Tenggara (Suryaningsih and Irhas 2014). Recently, sorghum is also consumed as a functional food (Suarni and Subagio 2013; Suarni 2016). Sorghum seeds contain many metabolites such as phenolic compounds that are beneficial for the prevention of chronic diseases, i.e., diabetes, hypertension, and heart disease (Stefoska-Needham et al. 2015) .

The development of sorghum as a food source needs to be accompanied by the development of superior varieties with characters of high-yielding, resistance to pests and diseases, well-adapted to marginal land, and high biomass and good grain quality. Indonesian released national varieties of sorghum were derived from local varieties, introduced lines, or mutations, which were developed through selection on yield and yield component traits. Donald (1968) stated that the farmers prefer ideal crops that possess desirable traits such as high yielding and good quality when grown in the farmers' environment. This preference has driven breeders to develop better varieties and encouraged them to design an ideal type (ideotype).

According to Donald (1968) most of the plant breeding is based on "shortcoming defects" or selection for grain yield (empirical breeding), namely by reducing genes that negatively affect yield potential and gradually collecting all yield component characters. Thus, yield improvement is usually performed without incorporation of designated physiological or morphological characters that could contribute to a greater yield, but only intended to improve yield in general (Saini et al. 2020) so that there is no information of the why or wherefore of that the variety shows a greater yield.

The other approach of empirical breeding is ideotype breeding. Ideotype breeding is a method of breeding to enhance genetic yield potential based on modifying individual traits where each trait's breeding goal (phenotype) is specified. A crop ideotype is an ideal type crop expected to have greater yield and better quality when developed as a cultivar. A crop ideotype will need a minimum input per unit of dry matter yielded (Donald 1968; Rasmusson 1987). The step of developing a crop ideotype has been reported (Rasmusson 1987; Gauffreteau 2018; Saini et al. (2020). According to Gauffreteau (2018) the steps include (i) defining the specifications of the 
varieties or breeding objective; (ii) designing and building the ideotypes (identification of single trait contributed to grain yield and defining minimum value of each trait); and (iii) assessing their ability to meet the specifications under several breeding cycles and across environments. The steps proposed by both authors are almost the same in practice. To develop an ideotype, knowledge about inheritance pattern of yield components and other related traits, trait interaction and their association with yield is also essential for the breeders (Saini et al. 2020).

This paper reports the results of a study to develop sorghum ideotypes for Indonesia. Until now, the main goal of sorghum breeding in Indonesia is to improve yield potential. One of the requirements for the release of sorghum varieties is the minimum yield potential of 5 tons $\mathrm{ha}^{-1}$. Designing the ideal plant type can help breeders to achieve this goal. There has been no published ideal type of sorghum for high yields, so it is necessary to design an ideal type of sorghum. Crop ideotypes can be designed by specifying the minimum phenotypic values of various agronomic, physiological, and morphological characters that contribute positively to the yield and incorporating them into a single genotype (Donald 1968; Saini et al 2020). Genotype that match the ideal type can be obtained from a simultaneous selection process based on an ideotype approach through ideotype breeding.

Information about the ideal type of sorghum for high yield potential will be very useful for breeders in making selection for grain yield improvement. The objective of this research was to design the ideal type of sorghum for high grain yield starting from the study of variability, selecting the characters that contribute to grain yield and determining the minimum phenotype value of each selected character and verifying the ideal type design for the selected lines in the following season.

\section{MATERIALS AND METHODS}

\section{Location and genetic materials}

The experiment was conducted for two seasons. The first season experiment was conducted from February to May 2018 at the Agriculture Research Center for Biotechnology and Genetic Resources, Bogor, West Java, Indonesia. Post-harvest handling was carried out at the Plant Breeding Laboratory of the Department of Agronomy and Horticulture, IPB University.

The genetic materials used in this study consisted of 56 $\mathrm{F}_{5}$ sorghum lines advanced from three segregating populations, derived from PI-10-90A $\times$ Numbu (A), PI150-20A $\times$ Numbu (B) and PI-150-20A $\times$ Kawali (C). Six national varieties, namely Numbu, Kawali, Pahat, Samurai 1 and Samurai 2, were used as check varieties, and two introduction lines (PI-150-20A and PI-10-90A).

\section{Working procedures}

The experiment was carried out in an Augmented Design with check varieties and three replicates. The seeds were planted at the space $70 \mathrm{~cm}$ between plant row and 15 $\mathrm{cm}$ between hill with four seeds per hill. The number of the plant was thinned at two weeks after planting to one plant per hill.

Dolomite was applied a month before planting with a dose of 1 ton $\mathrm{ha}^{-1}$. Urea, $\mathrm{KCl}$, and SP36 fertilizers were applied at dosages of $150 \mathrm{~kg} \mathrm{ha}^{-1}, 100 \mathrm{~kg} \mathrm{ha}^{-1}$ and $100 \mathrm{~kg}$ $\mathrm{ha}^{-1}$, respectively. One-third dose of Urea fertilizer was applied as a basal dose and 2/3 parts were given four weeks after planting. All the recommended agronomic and plant protection practices were carried out. Pesticide deltamethrin was applied once a week with a concentration of $1 \mathrm{ml} \mathrm{L}^{-1}$. The fungicide agrimycin was applied at five weeks after planting with a concentration of $2 \mathrm{ml} \mathrm{L}^{-1}$, and carbofuran $3 \mathrm{G}$ was applied in the top of a leaf at 7-8 week after planting. The observation was carried out on agronomic, morphological, physiological characters with eight plants of each line were observed as samples.

\section{Statistical analysis}

The data analysis included means for each character which were corrected by the presence of the effect of different growing environments. The adjusted means were calculated using formulas by Sharma (2006). The data were later analyzed with analysis of variances (ANOVA) using Rstudio v1.4.1106 with the agricolae package (de Mendiburu and Simon 2015; de Mendiburu 2021). Cluster analysis for genotypes was carried out using Statistical Tool for Agricultural Research (STAR) v2.0.1 software developed by IRRI (Gulles et al. 2014). Cluster analysis was performed using Euclidean distance and complete linkage clustering. Correlation analysis was conducted on the phenotypic data to determine the relationship between variables observed using Rstudio v1.4.1106, which is visualized using the ggplot2 package (Wickham 2016).

The Expected means squares were partitioned to estimate the component of variances based on the augmented design model. The environment variance $\left(\sigma_{e}^{2}\right)$ was calculated by dividing error mean squares with replication (MSe/r). The genetic variance $\left(\sigma_{g}^{2}\right)$ was obtained by subtracting lines mean squares with error mean square and divided with replication (MSg-Mse)/r)). The phenotypic variance was obtained from the sum of genetic and environmental variance $\left(\sigma_{g}^{2}+\sigma_{e}^{2}\right)$. Broad sense heritability $\left(h_{b s}^{2}\right)$ was obtained from a division of genetic and environmental variance $\left(\sigma_{g}^{2} / \sigma_{e}^{2}\right)$ and was classified into three groups; high broad sense heritability $\left(h_{b s}^{2}>0.5\right)$, medium broad sense heritability $\left(0.2 \leq h_{b s}^{2} \leq 0.5\right)$ and low broad sense heritability $\left(h_{b s}^{2}<0.2\right)$ (Stanfield 1983). The formula for calculation of the coefficient of genetic variance $(\mathrm{CVG})$ was $\left(\sqrt{\sigma_{g}^{2}} / \bar{x}\right) \times 100 \%$ with $\bar{x}$ was the population mean.

\section{Ideotype design}

The ideotype of sorghum for high yield was designed using selected characters based on the results of data analysis.

\section{Ideotype reassessment}

The ideotypes that have been determined were reassessed in the second season held from June 2018 to 
February 2019 at the Cikabayan Experimental Field, IPB University, Bogor, West Java, Indonesia. The experimental design and culture technique applied in land preparation, planting, fertilizing, crop management was the same as the previous planting season.

\section{RESULTS AND DISCUSSION}

\section{The performance of sorghum lines}

Sixty-four lines were evaluated in this study consisting of $56 \mathrm{~F}_{5}$ breeding lines, 6 national varieties, and 2 introduced lines. The breeding lines were generated by crossing between national varieties, introduced lines and selected through the pedigree method. The variance analysis showed highly significant differences among genotypes indicating the presence of genetic variability in the genetic materials evaluated. Performance of the genetic material evaluated is presented in Table 1.

Group 1 consisted of 27 lines which were characterized by high plant height and large leaf numbers. Group 2 consisted of 23 genotypes with large 100 grain weight characteristics and early flowering and harvesting characters. Group 3 consisted of 7 genotypes characterized by low 100 grain weight. Group 4 consisted of 5 genotypes that had the characteristics of stem diameter, flag leaf area, leaf greenness, green leaf percentage, panicle diameter, panicle weight, and large grain weight per panicle. Another distinct character in this group is the short panicle length. Group 5 consisted of 2 genotypes, namely Pahat and Samurai 2, characterized by long days to flowering and harvesting, and long panicle lengths, but have low phenotype values for other characters. This study also showed that the performances of the national varieties Pahat and Samurai 2 were distinct from those of other lines.

The nine A lines (generated from crosses of PI-10-90A $\times$ Numbu) in group 1 were similar to the female parent, namely PI-10-90-A, while the 10 lines $\mathrm{C}$ (generated from crosses of PI-150-20A $\times$ Kawali) were similar to the male parent, Kawali. The B lines (generated from crosses of PI$150-20 \mathrm{~A} \times \mathrm{Numbu})$ that were tested in this study and put into group 1 were not similar to the female parent (PI-15020-A) and the male parent (Numbu). Lines A and C which belonged to group 2 were not similar to their parents, while lines B were similar to their male parents (Numbu).

The $\mathrm{C}$ line in group 3 had a high degree of similarity with the female parent, while the $\mathrm{B}$ line did not resemble the two parents. Likewise, the lines A, B, and C which were included in group 4 were not similar to either the female or male parents.

The diversity of genetic material used in this study was obtained through dendrogram analysis. The genetic material tested formed five clusters at a similarity coefficient of about $75 \%$ (cluster image not shown). The lines of each group are shown in Table 2.

The dissimilarity of the tested lines with their parents was caused by the recombination of genes inherited by both parents and the selection processes that favored the recombinat lines. All tested $\mathrm{F}_{5}$ lines were selected using the pedigree method with large panicles size and medium plant height as the selected desirable traits. According to Elangovan et al. (2014) sorghum plants are classified as medium plant height if the height ranges from $151-225 \mathrm{~cm}$.

Table 1. Means and range of characters recorded for sorghum lines evaluated

\begin{tabular}{lrrl}
\hline Traits & Mean & $\begin{array}{c}\text { Standard } \\
\text { deviation }\end{array}$ & Range \\
\hline Plant height $(\mathrm{cm})$ & 218.7 & 42.0 & $117.7-316.0$ \\
Stem diameter $(\mathrm{mm})$ & 18.5 & 1.9 & $15.0-23.2$ \\
Leaf number & 10.6 & 1.1 & $8.0-12.8$ \\
Flag leaf area $\left(\mathrm{cm}^{2}\right)$ & 235.1 & 48.3 & $119.1-336.6$ \\
Leaf greenness (CCI units) & 47.8 & 3.5 & $38.0-57.1$ \\
Green leaf percentage (\%) & 66.2 & 14.2 & $32.1-89.6$ \\
Days to flowering (DAS) & 70.1 & 4.4 & $62.0-79.0$ \\
Days to harvesting (DAS) & 102.7 & 3.0 & $96.0-116.0$ \\
Panicle length (cm) & 20.2 & 2.8 & $14.9-28.2$ \\
Panicle diameter (mm) & 50.5 & 5.1 & $33.0-63.4$ \\
100 grain weight (g) & 2.8 & 0.4 & $1.8-3.6$ \\
Panicle weight (g) & 67.3 & 13.8 & $24.5-101.0$ \\
Grain yield per panicle (g) & 57.0 & 12.4 & $18.7-87.2$ \\
\hline
\end{tabular}

Table 2. Grouping of sorghum lines based on Euclidian distance and complete linkage method

\begin{tabular}{cl}
\hline Groups & \multicolumn{1}{c}{ Lines } \\
\hline 1 & A-122-20-6, C-119-17-1, A-075-5-9, B-371-5-6, A-375-5-1, B-075-21-2, C-083-18-3, A-349-5-13, A-273-11-2, C-374-7-2, \\
& B-252-15-11, C-191-17-8, C-133-14-16, C-238-13-7, B-078-18-11, A-242-11-5, C-267-18-18, C-374-7-1, C-114-18-8, A- \\
& 025-18-8, B-372-5-17, C-119-1-11, B-169-14-12, A-125-1-6, A-235-11-1, Kawali, and PI-10-90-A \\
2 & A-284-17-16, B-211-6-6, C-257-16-1, C-353-1-5, B-097-20-16, C-248-16-5, B-169-7-1, A-266-19-5, B-064-15-12, B-235- \\
& 15-4, B-144-9-5, B-139-17-14, B-132-19-5, B-263-7-8, A-125-19-11, B-043-6-9, A-324-2-15, N/UP-121-3, N/UP-151-3, \\
& N/UP-32-8, N/UP-39-10, N/UP-MERAH, and Numbu \\
3 & C-238-7-1, B-182-5-12, B-167-9-1, B-043-16-5, C-351-6-6, Samurai 1, and PI-150-20-A \\
4 & B-246-8-2, C-375-17-1, A-094-4-12, N/UP 118-7, and UPCA \\
5 & Pahat and Samurai 2
\end{tabular}




\section{The genetic variation and heritability of the observed traits}

Theoretically, information about the genetic parameters help breeders to choose the appropriate selection method and the suitable traits as selection criteria to achieve maximum genetic gain (Roy 2000; Menezes et al. 2014). In this case, genetic information is needed to know the level of genetic variability in the population. The genetic parameter values obtained in this study included environmental variance, genetic variance, phenotypic variance, heritability, and coefficient of genetic variability which are calculated based on the separation of the mean square value of each source of variance. The results showed that all the observed characters were highly influenced by genetic factors indicated by a high broadsense heritability, except for the green leaf percentage. The coefficient of genetic variance ranged from 2.0 to $23.2 \%$. The three characters with the lowest coefficient of genetic variance are recorded in green leaf percentage, and days to flowering and harvesting (Table 3 ).

Inheritance patterns of agronomic traits of sorghum have been reported (Trikoesoemningtyas et al. 2017; Rini et al. 2017; Al-Naggar et al. 2018). Sorghum is a plant with high genetic diversity reported by Schaffasz et al. (2019) on a population consisting of lines from various regions and sub-species. High value of heritability was recorded for plant height and grain yield per panicle (Al-Naggar et al. 2018). Rini et al. (2017) reported low heritability for yield and yield component traits of sorghum F1 populations under lines testers mating design. The breeding lines tested were generated from $\mathrm{F}_{2}$ population that showed high heritability values for plant height and moderate seed weight per panicle (Trikoesoemningtyas et al. 2017).

Simple morphological and physiological characters with high heritability values and a sufficient level of variability are very useful for designing ideal types for sorghum that have the potential to produce high grain weight per panicle. Based on heritability and CGV values, all observed characters, except for green leaf percentage and days to flowering and harvesting, can be used to design ideal plant types. However, information on the correlation of these traits with grain weight per panicle is still needed to establish the best traits to predict yield.

\section{The traits contributed to grain yield}

Correlation analysis using heatmap correlation shows that the panicle weight strongly reflects grain yield per panicle because the correlation value of these two characters is almost one (Figure 1). Therefore, in the sorghum breeding process, one of these two characters can be used as a target character to improve yield potential. Panicle weight trait can be observed with precision and easier than grain weight per panicle so this will also speed up the selection process, especially if the breeder works on segregated or large populations.

The characters of stem diameter $(\mathrm{r}=0.55)$, leaf number $(r=0.54)$, flag leaf area $(r=0.39)$, leaf greenness $(r=0.59)$, and green leaf percentage $(\mathrm{r}=0.36)$, and panicle diameter $(r=0.76)$ were positively and strongly correlated with grain yield per panicle. The results of this study also showed that there was a strong correlation between one character and another in stem diameter, leaf number, flag leaf area, leaf greenness, and green leaf percentage, and panicle diameter (Figure 1). Except for stem and panicle diameter, the four characters that were positively correlated with grain weight per panicle were characters related to photosynthetic capacity. The greater the phenotypic value of leaf number, flag leaf area, leaf greenness, and green leaf percentage, the greater the photosynthetic capacity of a genotype and thus the greater the grain weight per panicle. Stem diameter is a character that determines the ability of plants to store photosynthate which will be distributed into seeds. The character of stem diameter also determines the level of resistance to lodging.

Table 3. Genetic parameters value of traits recorded

\begin{tabular}{|c|c|c|c|c|c|}
\hline Characters & $\begin{array}{c}\text { Environtmental } \\
\text { variance } \\
\left(\sigma_{e}^{2}\right) \\
\end{array}$ & $\begin{array}{c}\text { Genetic } \\
\text { variance } \\
\left(\sigma_{g}^{2}\right) \\
\end{array}$ & $\begin{array}{c}\text { Phenotypic } \\
\text { variance } \\
\left(\sigma_{p}^{2}\right) \\
\end{array}$ & $\begin{array}{c}\text { Board sense } \\
\text { heritability } \\
\left(\mathbf{h}^{2}{ }_{\text {bs }}(\%)\right) \\
\end{array}$ & $\begin{array}{c}\text { Coeficient } \\
\text { genetic variance } \\
(\%)\end{array}$ \\
\hline Plant height & 120.5 & 1809.3 & 1929.9 & 93.8 & 19.9 \\
\hline Stem diameter & 1.3 & 2.5 & 3.7 & 66.5 & 8.5 \\
\hline Leaf number & 0.5 & 0.9 & 1.5 & 63.2 & 9.2 \\
\hline Flag leaf area & 514.4 & 2478.0 & 2992.5 & 82.8 & 21.5 \\
\hline Leaf greenness & 4.2 & 12.6 & 16.8 & 75.0 & 7.5 \\
\hline Green leaf percentage & 0.6 & 0.1 & 0.7 & 14.7 & 4.0 \\
\hline Days to flowering & 9.7 & 10.3 & 20.0 & 51.5 & 4.6 \\
\hline Days to harvesting & 3.1 & 4.3 & 7.3 & 58.3 & 2.0 \\
\hline Panicle length & 2.3 & 8.9 & 11.2 & 79.6 & 14.5 \\
\hline Panicle diameter & 7.7 & 29.0 & 36.7 & 78.9 & 10.7 \\
\hline 100 grain weight & 0.0 & 0.1 & 0.2 & 87.3 & 14.0 \\
\hline Panicle weight & 51.4 & 217.2 & 268.6 & 80.9 & 22.2 \\
\hline Grain weight per panicle & 44.1 & 170.9 & 215.0 & 79.5 & 23.2 \\
\hline
\end{tabular}




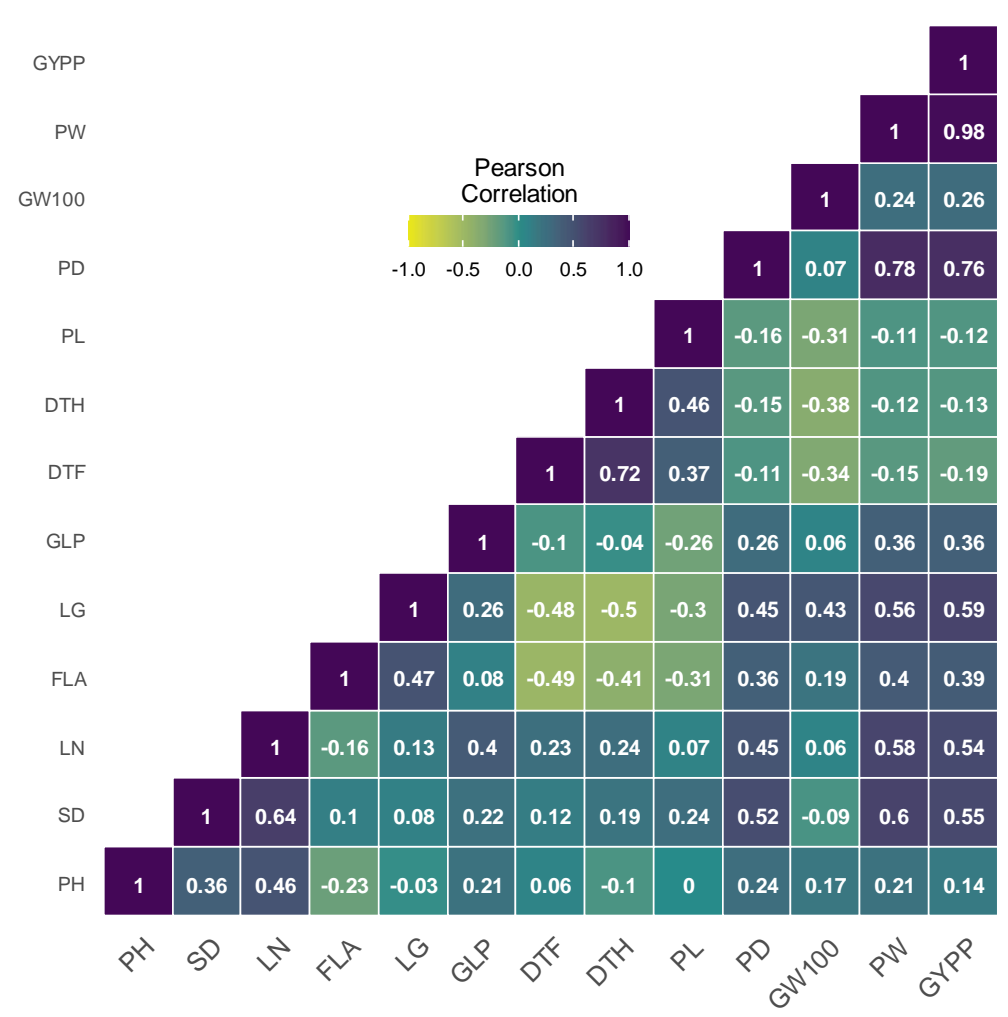

Figure 1. Correlation among characters in sorghum lines. Note: PH: Plant height; SD: Stem diameter; LN: leaf number; FLA: Flag leaf area; LG: leaf greenness; GLP: Green leaf percentage of green leaf; DTF: Days to flowering; DTH: Days to harvesting; PL: Panicle length; PD: Panicle diameter; GW100: 100 grain weight; PW: Panicle weight; and GYPP: Grain weight per panicle

Plant height had a positive $(\mathrm{r}=0.14)$ but weak correlation with grain weight per panicle (Figure 1). Most of the tested lines were breeding lines that were selected since the $F_{2}$ generation to obtain a genotype with moderate plant stature with plant heights ranging from $150-225 \mathrm{~cm}$. This is because plants from the Gramineae group with medium plant height generally have high seed yields, short harvesting dates, and are resistant to lodging.

In order to develop high-yielding ideotypes, several traits were identified as a key for improvement of sorghum yield potential. Ali et al. (2011) reported that flag leaf area and dry leaf matter could be exploited as simple morphophysiological markers for higher grain yield. Dawood (2011) concluded that grain filling duration had a significant positive correlation with grain yield and can be used to improve yield in sorghum. According to Alikhani et al. (2012), the number of leaves plays an important role in increasing the seed weight in sorghum because it determines the amount of solar energy captured in photosynthesis. According to Semenov and Stratonovitch (2013), the main traits contributing to yield increase were light conversion efficiency and duration of grain filling resulting in a higher harvest index.

Sulistyowati et al. (2016) found that sorghum grain weight per panicle was positively correlated with stem diameter, number of leaves, and panicle diameter. The cumulative amount of intercepted radiation and transpiration during the growing season is influenced by the pace of canopy growth and attainment of optimal canopy development and leaf area index (Senapati et al. 2019).

\section{Designing an ideotype of sorghum}

An optimal plant type design (crop ideotype) is required to obtain a genotype with several traits that assist the enhancement of yield potential. Characters with significant genetic diversity, highly correlated with grain weight per panicle or panicle weight, and positively correlated among the selected characters were used to create the optimal type of plant. The next step is to determine the phenotype's minimal value for each character.

There is no optimal sort of plant design for sorghum in Indonesia yet. Not so with rice, the optimal rice variety has the following characteristics: erect and dark green leaf, short plant height $(80-100 \mathrm{~cm})$, sturdy stem, productive tillers (8-10 tillers), and long panicle shape with 200-250 grains per panicle) (Kush 2000). New plant-type rice yield of roughly $20 \%$ over the non-plant-type rice cultivars with similar yields. The ideal plant type for wheat was developed by Donald (1968).

According to Saini et al. (2020), the notion of a plant's ideotype can be produced by changing the current genotypes to create a better genotype and redesigning the ideotype. The other method is to start with a breeding goal, choose the best genotypes, and specify all qualities related to the genotypes. The concept of the sorghum ideotype was formed in the study based on the goal of breeding, the findings of genetic study, and the best lines from the existing lines, including some national varieties. 
The goal of the sorghum breeding presented in this study is to increase yield potential. The results of the genetic study revealed that the characters of stem diameter, leaf number, flag leaf area, leaf greeness, green leaf percentage, and panicle diameter all contributed positively to grain yield increase and had high heritability values, indicating that the six characters plus plant height could be considered as the characters for developing the ideal sorghum (new plant type sorghum).

The sorghum ideotype for obtaining a genotype with high grain weight per panicle has a phenotypic value of $150-235 \mathrm{~cm}$ for plant height (Table 4). For stem diameter, leaf number, flag leaf area, leaf greenness, green leaf percentage, and panicle diameter, the minimal values are $17 \mathrm{~mm}, 10,209 \mathrm{~cm}^{2}, 44 \mathrm{CCI}$ units, 48 percent, and $49 \mathrm{~mm}$, respectively.

For plant height, it is directed to obtain a line with a medium plant height. Plant height is important for plants from the Gramineae group because it is related to resistance to lodging and harvest time. In addition, farmers highly consider maturity date as it is related to the growing season. For example, sorghum is recommended to be planted at the end of the rainy season after the rice harvest. Therefore, choosing a line with a medium plant height makes it possible to obtain a line with a more early harvesting date.

Using the selected $\mathrm{F}_{6}$ lines, the ideal type design established in the first season was validated in the following season. The yield potential of the ten selected $F_{6}$ lines ranged from 63.8 to 87.8 grams per panicle. Nine out of the thirteen lines with the highest potential yield matched the ideal type set in the previous generation. Because their plant stature exceeded $235 \mathrm{~cm}$, the other four lines were not included in the ideal type. Table 5 shows the best $\mathrm{F}_{6}$ lines performance as well as their suitability for the ideal type. These lines have a potential dry grain yield of 6.1-8.1 tons ha-1.
Simultaneous selection based on a predefined ideotype, i.e. selecting individuals with a predetermined minimum value for each character, can yield the ideal type of plant. The characters used to define the best plant type were stem diameter, leaf number, flag leaf area, leaf greenness, green leaf percentage, and panicle diameter, chosen based on heritability values and correlation with grain weight per panicle. The best plant height for the Gramineae family to support high yields is a medium plant height as confirmed by previous studies (Donald 1968; Donald 1979; Schaffasz et al. 2019).

Donald (1968) was successfully established the concept of an ideal wheat type based on morphological characteristics. The ideal sorghum variety was created in this study based on simple morphological and physiological characteristics of stems, leaves, and panicles, but the root system had to be included. In the future, the concept of an ideal crop will need to be built by incorporating not only morphological and physiological traits, but also biochemical traits to enrich the concept of crop ideotype, because breeding goals change with climate change and weather, national policies, and market demand.

Table. 4. The mean value and phenotypic range of sorghum with high yield potential

\begin{tabular}{llc}
\hline Characters & Mean & Range \\
\hline Plant height $(\mathrm{cm})$ & 205.2 & $150.4-234.4$ \\
Stem diameter $(\mathrm{mm})$ & 20.1 & $17.0-22.0$ \\
Leaf number & 11.4 & $10.4-12.8$ \\
Flag leaf area $\left(\mathrm{cm}^{2}\right)$ & 267.9 & $208.8-336.3$ \\
Leaf greenness o (CCI units) & 50.1 & $44.3-57.1$ \\
Green leaf percentage $(\%)$ & 71.9 & $48.4-89.3$ \\
Panicle diameter (mm) & 55.5 & $49.4-63.4$ \\
Grain weight per panicle $(\mathrm{g})$ & 70.2 & $63.8-85.3$ \\
\hline
\end{tabular}

Table 5. Yield potential of the $\mathrm{F}_{6}$ lines and the supporting architecture characters

\begin{tabular}{|c|c|c|c|c|c|c|c|}
\hline Lines & $\begin{array}{c}\text { Plant } \\
\text { height } \\
(\mathrm{cm})\end{array}$ & $\begin{array}{l}\text { Stem diameter } \\
(\mathbf{m m})\end{array}$ & $\begin{array}{c}\text { Leaf } \\
\text { number }\end{array}$ & $\begin{array}{c}\text { Panicle } \\
\text { diameter } \\
(\mathbf{m m})\end{array}$ & $\begin{array}{c}\text { Grain weight } \\
\text { (g) }\end{array}$ & $\begin{array}{c}\text { Expected } \\
\text { grain yield } \\
\text { potential } \\
\left(\text { ton } \text { ha }^{-1}\right)\end{array}$ & Type \\
\hline PI 10/N-125-1-6-1 & 285.3 & 25.72 & 17 & 67.48 & 78.45 & 7.5 & $\mathrm{X}$ \\
\hline PI $150 / \mathrm{N}-252-15-11$ & 282.2 & 23.14 & 16 & 71.08 & 87.83 & 8.4 & $\mathrm{X}$ \\
\hline PI $10 / \mathrm{N}-349-5-13-6$ & 276.8 & 19.95 & 12 & 51.69 & 69.85 & 6.7 & $\mathrm{X}$ \\
\hline PI $150 / \mathrm{N}-246-8-2-1$ & 240.9 & 21.21 & 15 & 59.78 & 80.03 & 7.6 & $\mathrm{X}$ \\
\hline PI $150 / \mathrm{K}-374-7-1-1 *$ & 209.8 & 21.42 & 15 & 56.54 & 64.25 & 6.1 & V \\
\hline PI $10 / \mathrm{N}-324-2-15-2 *$ & 201.0 & 24.33 & 14 & 61.98 & 70.38 & 6.7 & $\mathrm{~V}$ \\
\hline PI $150 / \mathrm{N}-169-7-1-7 *$ & 197.5 & 21.69 & 14 & 53.28 & 76.82 & 7.3 & $\mathrm{~V}$ \\
\hline PI $150 / \mathrm{K}-248-16-5-3 *$ & 196.2 & 23.26 & 16 & 54.93 & 75.98 & 7.2 & $\mathrm{~V}$ \\
\hline PI $150 / \mathrm{N}-043-16-5-5$ & 181.6 & 23.17 & 12 & 58.51 & 70.08 & 6.7 & V \\
\hline PI $150 / \mathrm{N}-043-6-9-8$ & 170.8 & 21.24 & 15 & 51.73 & 64.09 & 6.1 & V \\
\hline PI $150 / \mathrm{K}-375-17-1-5$ & 165.9 & 23 & 16 & 54 & 63.82 & 6.1 & V \\
\hline PI $150 / K-375-17-1-1$ & 165.7 & 25.83 & 16 & 52.85 & 68.63 & 6.5 & V \\
\hline PI 150/N-182-5-12-7* & 164.5 & 25.33 & 14 & 60.69 & 85.32 & 8.1 & $\mathrm{~V}$ \\
\hline Rata-rata & 206.8 & 23.1 & 14.6 & 57.5 & 72.7 & 6.9 & \\
\hline
\end{tabular}

Note: V: ideal type; X: non-ideal type: line with * is from Andriani 2019 
The term "ideotype" refers to a breeder's decision to combine all traits that positively contribute to grain yield into a single plant genotype (Saini et al. 2020). Selection based on ideotype-approach might be a good technique to come up with better lines. It will also be simpler if the qualities can be measured simply and precisely, and if they are less influenced by environmental influences (Gauffreteau 2018). The research-based sorghum ideotype design with high yield potential can be used as a template for developing crop ideotypes for various growing conditions or special requirements, such as pest and disease resistance or higher grain quality. This suggests that the ideotype of a crop may vary in response to environmental changes.

\section{ACKNOWLEDGEMENTS}

The authors would like to acknowledge the Indonesia Directorate General of Higher Education (DIKTI) for financial support (under PTUPT Research Grant financial year 2018-2019 and 2021). The author also would thank all parties who helped in data collection and work on this research.

\section{REFERENCES}

Alikhani MA, Etemadi F, Ajirlo AF. 2012. Physiological basis of yield difference in grain sorghum (Sorghum bicolor (L.) Moench) in a semi-arid environment. Am J Agric Biol Sci 7 (7): 488-496.

Ali MA, Abbas A, Awan SI, Jabran K, Gardezi SDA. 2011. Correlated response of various morpho-physiological characters with grain yield in sorghum landrace at different growth phase. J Anim Plant Sci 21 (4): 671-679.

Al-Naggar AMM, El-Salam RMA, Hovny MRA, Yaseen WYS. 2018 Variability, heritability, genetic advance and interrelationships for agronomic and yield traits of sorghum B-lines under different environments. Asian J Biochem Genet Mol Biol 1 (1): 1-13. DOI: 10.9734/AJBGMB/2018/41210.

Andriani D, Wirnas D, Trikoesoemaningtyas. 2019. Efektivitas metode seleksi pedigree dan modified bulk pada tiga populasi sorgum (Sorghum bicolor (L.) Moench). Jurnal Agronomi Indonesia 47 (3): 275-282. DOI: 10.24831/jai.v47i3.27661. [Indonesian]

Dawood WM. 2011. Relationships between grain filling durations and grain yield in Sorghum (Sorghum bicolor (L.) Moench). Diyala Agric Sci J 3 (1): 60-66.

Donald CM. 1968. The breeding of crop ideotypes. Euphytica 17: 385 403. DOI: $10.1007 / \mathrm{BF} 00056241$.

Donald CM. 1979. A barley breeding programme based on an ideotype. J Agric Sci 93 (2): 261-269. DOI: 10.1017/S0021859600037941.

de Mendiburu F, Simon R. 2015. Agricolae-ten years of an open source statistical tool for experiments in breeding, agriculture and biology. Peer J 3: e1404v1. DOI: 10.7287/peerj.preprints.1404v1.

Gauffreteau A. 2018. Using ideotypes to support selection and recommendation of varieties. Oilseeds fats Crops Lipids 25 (6): 1-9. DOI: $10.1051 / \mathrm{ocl} / 2018042$.
Gulles AA, Bartolome VI, Morantte RIZA, Nora LA. 2014. Randomization and analysis of data using STAR (Statistical Tool for Agricultural Research. Phillip J Crop Sci 39 (1): 137.

Khush GS. 2000. New plant type of rice for increasing the genetic yield potential. In J.S. Nanda (edn.). Rice Breeding and Genetics: Research Priorities and Challenges. The Science Publishers, Rawalpindi.

Menezes CB, Carvalho Júnior GA, Silva LA, Bernardino KC, Souza VP, Tardin FD, Schaffert RE. 2014. Combining ability of grain sorghum lines selected for aluminum tolerance. Crop Breed Appl Biotechnol 14: 42-48. DOI: 10.1590/S1984-70332014000100007.

Rasmusson DC. 1987. An evaluation of ideotype breeding. Crop Sci 27 (6): 1140-1146. DOI: 10.2135/cropsci1987.0011183X002700060011x.

Reddy BVS, Ramesh S, Reddy PS, Ramaiah B, Salimath PM, Rajashekar K. 2005. Sorghum: A potential alternate raw material for bio-ethanol and bioenergy. J Sat Agric Res 1 (1): 1-8.

Rini EP, Wirnas D, Trikoesoemaningtyas, Sopandie D. 2017. Genetic analysis on agronomic and quality traits of sorghum hybrids in Indonesia. SABRAO J Breed Genet 49 (2): 192-200.

Roy D. 2000. Plant Breeding, Analysis and Exploitation of Variation. Narosa Publishing House, New Delhi.

Saini P, Singh C, Kumar P, Bishnoi SK, Francies RM. 2020. Breeding for Ideotype Designing. In Kumar A, Prasad B, Kuma A (eds) Classical and Molecular Approaches in Plant Breeding. Narendra Publishing House, New Delhi

Schaffasz A, Windpassinger S, Friedt W, Snowdon R,Wittkop B. 2019. Sorghum as a novel crop for Central Europe: Using a broad diversity set to dissect temperate-adaptation. Agronomy 9 (9): 535. DOI: 10.3390/agronomy9090535.

Semenov MA, Stratonovitch, P. 2013. Designing high-yielding wheat ideotypes for a changing climate. Food Energy Secur 2 (3): 185-196 DOI: $10.1002 /$ fes3.34

Senapati N, Brown HE, Semenova MA. 2019. Raising genetic yield potential in high productive countries: Designing wheat ideotypes under climate change. Agric For Meteorol 271: 33-45. DOI: 10.1016/j.agrformet.2019.02.025.

Sharma JR. 2006. Statistical and Biometrical Techniques in Plant Breeding $1^{\text {st }}$ Edition. New Age International, New Delhi.

Suarni. 2016. Peranan sifat fisikokimia sorgum dalam diversifikasi pangan dan industri serta prospek pengembangannya. Jurnal Litbang Pertanian 35 (3): 99-110. DOI: 10.21082/jp3.v35n3.2016.p99-110. [Indonesian]

Suarni, Subagio H. 2013. Potensi pengembangan jagung dan sorgum sebagai sumber pangan fungsional. Jurnal Litbang Pertanian 32 (2): 47-55. DOI: 10.21082/jp3.v32n2.2013.p47-55. [Indonesian]

Sulistyowati Y, Trikoesoemaningtyas, Sopandie D, Ardie SW, Nugroho S. 2016. Parameter genetik dan seleksi sorgum [Sorghum bicolor (L.) Moench] populasi F4 hasil single seed descent (SSD). Jurnal Biologi Indonesia 12 (2): 175-184. [Indonesian]

Suryaningsih R, Irhas. 2014. Bioenergy Plants in Indonesia: Sorghum for producing bioethanol as an alternative energy substitute of fossil fuels. Energy Procedia 47: 211-216. DOI: 10.1016/j.egypro.2014.01.216.

Stanfield WD. 1983. Theory and Problem of Genetics $2^{\text {nd }}$ Edition. McGraw-Hill, New York.

Stefoska-Needham A, Beck EJ, Johnson SK, Tapsell LC. 2015. Sorghum: An underutilized cereal whole grain with the potential to assist in the prevention of chronic disease. Food Rev Intl 31 (4): 401-437. DOI: 10.1080/87559129.2015.1022832.

Trikoesoemaningtyas, Wirnas D, Saragih EL, Rini EP, Sari M, Marwiyah S, Sopandie D. 2017. Kendali genetik karakter morfologi dan agronomi pada tiga populasi sorgum (Sorghum bicolor (L.) Moench). Jurnal Agronomi Indonesia 45 (3): 285-291. DOI: 10.24831/jai.v45i3.18387. [Indonesian]

Wickham H. 2016. ggplot2: Elegant Graphics for Data Analysis. SpringerVerlag, New York. 